Seloka: Jurnal Pendidikan Bahasa dan Sastra Indonesia
$9(2)(2020): 147-158$
UNNES
https://journal.unnes.ac.id/sju/index.php/seloka

\title{
The Literary Style of Javanese Female Characters in the Novel Jemini by Suparto Brata
}

\author{
Krisnani Widyaningsih ${ }^{\circledR}$ Bambang Indiatmoko ${ }^{2}$ \\ DOI: https://doi.org/10.15294/seloka.v9i2. 37887 \\ ${ }^{1}$ SMP N 1 Winong Pati, Jawa Tengah, Indonesia \\ ${ }^{2}$ Universitas Negeri Semarang, Indonesia
}

\begin{abstract}
Article Info
Abstract

History Articles

Received:

18 March 2020

Accepted:

18 June 2020

Published:

21 August 2020

Keywords:

Javenese women

figure,

novel, Suparto Brata

Women in the journey of human life have an important role, namely; give birth, nurture and educate their children. Mental education for women began to be developed, one of them through literary novels. The Novel Jemini by Suparto Brata presents the femininity of Javanese women from an objective point of view. Another interesting part of the novel is the strong characterization of Javanese women. This is emphasized by the use of various styles of language and diction which aim to uncover the struggle for life of Javanese women leaders. The objectives of this study are (1) Describe the characterization of Javanese women in the novel Jemini by Suparto Brata; (2) Uncovering the struggle for life of Javanese female characters in the novel Jemini by Suparto Brata; (3) Describing the lliterary style of Javanese female characters in the novel Jemini by Suparto Brata. This literary research uses the approach of feminism which is sulking in the Javanese feminism model. The data used in the form of fragments of text in the novel Jemini by Suparto Brata contained the characterization of Javanese women. Source of text data in the novel as a whole. The study's method is semiotic structuralism with hermeneutic techniques. The results of this study indicate the feminism of Javanese women in the characterization of the novel Jemini by Suparto Brata. The lliterary style of the female characters in the novel consists of; words, sentences, phrases, figurative languages show the existence of feminism in the novel Jemini by Suparto Brata. The character of Javanese women in the novel is clever, broad-minded, always curious, shy, agile, nimble, diligent in working, strong-minded, patient and accepting, sympathetic, respectful towards parents, and adults. This research raises awareness for the public about the role of women.
\end{abstract}

\footnotetext{
Correspondence address:

J1. Raya Winong-Gabus Km 0.5 Pati, Jawa Tengah

E-mail: krisyeonnie@gmail.com
} 


\section{INTRODUCTION}

"Perempuan" or woman in Indonesian comes from the root word "empu" which means master, someone who is proficient, powerful, honorable or glorified. The word woman can be concluded to be the absolute owner of her body and to be her own master. The word woman in Javanese etymology has the meaning of "wani ditata" (dare to get policed). Handayani (2008) explains the meaning of "wani ditata", which means that she allows herself to be policed in a rule that has determined her position and her responsibility.

The role of women in human's journey is to give birth, nurture and educate their children. A good mother will produce good children; on the contrary, a bad mother, who does not take a good care of her children's well-beings will create a dilapidated next generation (Asri, 2013). A Woman has double roles which are as wife and as mother. A wife must be able to play a role as a lover, friend, best friend, relative, who is always ready to live together with her partner (male). Literary work is the result of the outpouring of sentimental feelings and abstractions of a mental universe, both through consciousness and the subconscious to understand human life (Udayana, 2017). Speaking of literary works, novels are one type of literary work that presents the reality of human life. Indonesian novel that raises the topic of women, there are some great novelists who write about women's problems including Marah Rusli who wrote the novel Siti Nurbaya. When the women's movement was just beginning, the position of women was still very low. In the era when Takdir wrote Layar Terkembang, fourteen years later from Siti Nurbaya, published in 1922, the situation of women was better. Many women leaders such as Tuti have fought for the emancipation of women to get a better position for women, for the advancement of women for themselves and for the progress of the nation's homeland. Four years later, in 1940, when Belenggu was written by Armijn Pane, the results were seen in many educated women, relationship between women and women or between women and men (Pradopo, 2009).

The role of women as a story lines' activator is not only found in Indonesian novels. Long before that, Javanese literary work, Ramayana written by Walmiki and Mahabarata written by Begawan Byasa, had talked about the influence of female figures. The female lead (Dewi Shinta) in the Ramayana is known for her loyalty and patience in facing hardships. Her purity and loyalty to Ramawijaya (her husband) prevented her body from burning by fire. The position of such a female character is also evident in the early Javanese novel namely, Serat Riyanta and Suwarsa-Warsiyah Sadewa (in Susanto, 1992). Thus, the role of women in the success of men is not new, but has existed since ancient times.

The novel Jemini by Suparto Brata presents the femininity of Javanese women from a different angle. Previously, Suparto Brata presented many roles of women with modernity, with their role in the public and higher education. In Jemini, Suparto Brata precisely displays the femininity of women close to the domestic affairs in the past setting. Of course, the author then tries to adopt the potential of the environment as a complex social system. This needs to be done (Zulaeha, 2013), the domestic role of women in Javanese terms is divided into three main tasks which are called tiga -ur terms (kasur(mattress), dapur(kitchen), and sumur (well)). The author wants to convey the message that, what is meant by feminism is not merely wanting to equalize or compete with men, but to show the role of women in fighting for their dignity.

In addition to the setting, another interesting thing that was presented in the Jemini novel was the use of local colors as reported by Sahid (in Supriyanto, 2014) very strong especially in the genre of the novel. The term local color or regional color according to Wolf (1994) is a characteristic of an area that is detailed in fictional stories such as in settings (settings), dialects and customs (clothing and ways of thinking).

Feminism in Jemini can be understood through a thorough study of the interwoven 
elements. The theory which breaks things down into interrelated elements is the theory of structuralism. In addition, because the main nature of language as a sign system is its relational nature, the overall relationship or opposition between its elements and aspects must be understood (Yasa, 2014). The objectives of this study are (1) describe the characterization of Javanese women in the novel Jemini by Suparto Brata; (2) uncovering the struggle for life of Javanese female characters in the novel Jemini by Suparto Brata; (3) describing the language style of Javanese female characters in the novel Jemini by Suparto Brata. This research benefits the community should be aware of the noble role of women so, that there is no longer any cultural construction that considers women as secondclass individuals. This research raises awareness for the public about the role of women.

\section{Javanese Female Characters}

The theory of women expressed in the element of mentality in literary structure of prose (novel) figures and characterizations. Valentina (2010) states that story figures are actors. The focus of point of view on women is directed at the concepts of feminism. According to Wolf (1994), the feminism movement demanded was the selfesteem of women, Javanese women. The term is translated as a woman who was educated in Javanese culture on an emotional level as the power of her femininity (Handayani, 2008). Literary research with an objective on the values, benefits or usefulness of literary works in human life (Faizin, 2017). Therefore, this study needs to summarize the theory of semiotic structuralism for the regulation of intrinsic and semiotic structural relations of the signs raised by the author (Junus, 1981).

\section{Novel}

The genre of this literature has a different structure from the literary form of poetry and drama. The novel has a prose structure consisting of extrinsic structure which includes the point of view of the author, literature, and reader as well as intrinsic which includes physical and mental elements. Theory of structural criticism is more concerned with the meaning of literary works. (Hartoko, 1982). The physical elements used to identify are plots, figurative language, points of view, themes, and paths, while the intentions arranged from diction units are examined using diction language styles, sentences, and paragraphs. The study of Javanese diction in the language style requires a Javanese approach that includes dasanama, camboran and plutan. Study of Javanese sentence forms requires unen-unen theory which includes bebasan, paribasan and saloka, isbat. This is a series of artistic space structures in Literary works. In the form of paragraphs in Javanese format, things that need to be prepared include gancaran and pacelathon (Supriyanto, 2011).

\section{METHODS}

Feminism's approach to structuralsemiotics is needed to process detailed information about the characterizations contained in the novel. Analysis of the structural findings is then identified through language style. The semiotic method is used as a means of discovering the characteristics of feminism contained in diction, sentence and paragraph styles. The following data is the data source for the approach taken. 
Tabel 1. Characterization Javanese Women

\begin{tabular}{|c|c|c|c|c|}
\hline $\begin{array}{l}\text { No } \\
1 .\end{array}$ & Data's Code & Data & Transcription & Page \\
\hline \multirow[t]{9}{*}{1.} & J01 & "Omongmu! Kowe ki diwasa & & 79 \\
\hline & & durung setaun jagung! & "Your words! You are not & \\
\hline & & Pretikelmu wis kaya wong & yet an adult! You act like & \\
\hline & & tuwa wae. Saiki ora perkara & an old man. Now it & \\
\hline & & kowe seneng opo ora seneng! & doesn't matter if you like it & \\
\hline & & Kowe ki wong wedok. Isane & or not! You are a girl. & \\
\hline & & mung disenengi wong & Usually only liked by & \\
\hline & & lanang! Anggepmu apa kowe & men. You think you can & \\
\hline & & $\begin{array}{l}\text { oleh sakarepmu, seneng } \\
\text { wong lanang?!" }\end{array}$ & choose any man you like " & \\
\hline
\end{tabular}

The research data were obtained through literature studies and the first level of semiotic reading techniques, namely heuristic readings. this reading is based on linguistic conventions. After being collected, the data is clarified according to the type of problem, namely aspects of sound, words, phrases, sentences and speech fragments that contain elements of the struggle of the female characters in the structure of prose (novel) literature.

\section{RESULTS AND DISCUSSION}

The results of the study presented in this chapter include (1) structural data about characterizations in the novel (2) the style of words, phrases, sentences and figurative language in the novel (3) the struggle for the lives of Javanese women in the novel Jemini by Suparto Brata.

\section{Characterization of Javanese Women in The Novel Jemini By Suparto Brata}

Jemini is a complex figure of round character (round figure) who represents the personality of Javanese women who have complex tenderness, strength and intelligence. Judging from his involvement in the story Jemini is a central figure, it can be seen from the topic of the story that tells the development of Jemini's life starting from Jemini's childhood, Jemini's adolescence, to be an adult and has her own family. Supporting female figures are Emak Semi, Ngadinem, Mak Raji, Siti, Kadinah, Mak Siti, Sum, Mak Talib, Parni. To find out the characterizations of these figures, the character characterizations will be discussed below. Data is described through direct and indirect depictions 
Tabel 2. Characterization of Javanese Female Figures

\begin{tabular}{|c|c|c|}
\hline No & Characters & Characterization \\
\hline 1 & Jemini & $\begin{array}{l}\text { Stubborn, clever, always curious, shameless, naive, } \\
\text { agile, fight / rebel, skilled, diligent, honest, strong } \\
\text { opinion, patient and accepting, sympathy, polite, } \\
\text { mature, disciplined, responsible, steadfast, } \\
\text { conscientious, independent, attractive, attractive } \\
\text { motherhood. }\end{array}$ \\
\hline 2 & Mak Semi & $\begin{array}{l}\text { Stubborn and light hand, friendly, likes to compare, } \\
\text { ngemong. }\end{array}$ \\
\hline 3 & Mak Thalib & Hard worker, polite, like to help. \\
\hline 4 & Siti & Brave, flirty, sympathetic. \\
\hline 5 & Mak Siti & Spry or skillful, responsible. \\
\hline 6 & Ngadinem & $\begin{array}{l}\text { Like showing off and flirty, low self-esteem and } \\
\text { discouraged. }\end{array}$ \\
\hline 7 & Sum & Pampered, innocent. \\
\hline 8 & Kadinah & $\begin{array}{l}\text { Not confident, easily jealous, accept the situation / } \\
\text { surrender. }\end{array}$ \\
\hline 9 & Mak Raji & Fierce, like insulting and arrogant. \\
\hline 10 & Parni & Likes to advise and be honest. \\
\hline
\end{tabular}

The main character in the novel is a woman named Jemini but besides Jemini's character who portrays the complex character of Javanese women's struggle there are also other female figures including Emak Semi, Ngadinem, Mak Raji, Siti, Kadinah, Makne Siti, Sum, Mak Talib, and Parni . Among the ten female figures, Jemini is the only figure who has a complex character who is able to represent the characters of the struggle of Javanese women. Jemini's character is not only fighting for his fate. The female figure presented by Suparto Brata is able to interact with other female leaders who experience oppression and try to arouse enthusiasm to overcome all problems experienced by other female leaders.

Jemini's figure inspires readers about how domestic is becoming a great strength of women in the fabric of life. Where domestic is a sector dominated by women which makes it so influential in a household setting. Jemini's figure changed the community's view of Javanese women who had been constructed as weak creatures who only depend on men.

The characterization of Jemini's figure opened up an insight into the struggle of Javanese women in life. Since Jemini was young she has been formed into a skilled and independent person by her mother. Although in some illustrations the figure of a small Jemini has a personality that tends to be stubborn, tomboy, rebellious and wants to be free, but basically we can see in the whole text of the novel depicting a personal figure who is chosen, patient, steadfast, mature, responsible, disciplined, honest, diligent, polite, and motherly.

Jemini's character in the analysis of the characterization of Javanese women emphasized that Javanese women are symbols of struggle in instilling morality, virtue, independence, care, discipline, compassion, self-sacrifice, patience, sincerity, and responsibility. The presence of a female figure in the middle of the family carries the burden of idealization which is also the reason why she must be respected. The existence of a woman at the beginning of a child's life is a spirit that blows affection in the lives of her children. 
The Style of Javanese Figures in The Novel Jemini by Suparto Brata

Word Selection

Fiction in the literary context is the author's choice of words to express his ideas in order to achieve certain effects in his literature. Based on this, the novel Jemini by Suparta Brata often found the use of foreign languages, Arabic, Javanese or Arekan dialect or Suroboyoan and Sundanese.

\section{The Use of Synonyms}

The equivalent word (synonym) or in Javanese is called tembung saroja which is a word that has a different form but has the same or almost the same meaning. For Javanese, the use of synonym is often found in naming puppet characters such as Rahwana who is also debuted with Dasamuka. The use of synonyms in a sentence is caused by the existence of the same sense of taste, for example in the words Oom, Lik (Pak Lik) and Wak (Uwak) or Raden, Ndara and Tuan to provide the effect of affirmation or affirmation that the character is very nervous.

\section{Morphology}

Words that have the potential to become word are categorized as actual or potential words. These words can be accepted in form and meaning (Luthfiani, 2020). The novel Jemini by Suparto Brata utilizes (1) compound words, compound words in Javanese called tembung camboran, this word comes from the Kawi language cambor which means campur (mixed) and suffixed -an (Poerwadarminta, 1939). The word kembang setaman is a compound word because it consists of two elements, namely the word kembang and the word setaman. The word compound kembang setaman is used to name a type of water used for splash water. Setaman flower is a flower mixture consisting of various flowers mixed with water. The phrase "bathing with setaman flower" is closely related to local customs and beliefs as a means of selfpurification. Javanese people use kembang setaman or setaman flower for sacred traditional ceremonies. (2) Shortening of words found on page 75 Iya, tah? Yok apa sé, lèk gaé sop sing disenengi? ( $\mathrm{J}$ / 75). Yok apa in Javanese, SoloJogja, is written with the words kenapa sih (why), while lèk gaé is written in carane gawe (how to work). The shortening of the words on the page 75 shows a straightforward impression on the speech.

The word $k a$ is a shortening of the word from saka which means from where, whereas the word lik should be bulik or in Indonesian the meaning is aunt and then the word $y u$ should be written mbakyu which means sister. In arekan dialects, words tend to be shortened, and it is also seen in the words / njuk Sum / which is on page 18 , the word njuk should be written njaluk which means to ask for. The shortening of the words above is intended to create an immediate impression.

\section{The Use of Repetition}

The use of repetition in the novel is commonly found. Combination of words in the form of repetition gives the impression of overheating or exaggerating, Pradopo in (Supriyanto, 2012). The word surak-surak gives the impression of a very boisterous shouting which is shared by several people simultaneously. This form of repetition is repetition of a complete root word. The word mangar-mangar gives the impression of being very radiant or blushing. This form of repetition is repetition of a complete root word. Like mangar, the word moreh-moreh in quotation page 76 also has meaning "very" and also comes from repetition of the basic form. The word bekuh-bekuh gives the impression of being annoyed to grumble. While the word adik-adike is repeated to state the number or sulking at numbers (numeralia) because Jemini's sibling is more than one.

\section{Basic Form Deviations}

The use of basic forms taken from the Indonesian language is found in the novel Jemini by Suparto Brata. The word mbilangi is derived from the root word bilang (telling) which gets the prefix $m$-and suffix $-i$. The word mbilangi was spoken by Semi to accent like westerners accustomed to mixing Indonesian and Javanese accents. In the word diambilken (being brought), 
it is derived from the root word ambil with prefix in-and suffix ken. The word diambilken is said by Wagiman when offering drinks to Piet. The deviation in the basic form in Jemini's appears in the utterances of foreign figures or local figures who are talking to people from the Netherlands. Local leaders want to adjust to the words of foreign figures so that the message can be understood. Phraseology

\section{Typical expression of Javanese}

Jemini's is a Javanese novel that takes place in the aftermath of Dutch colonialism. Because this novel is in Javanese, there are many Javanese expressions in this novel. Examples of expressions or paribasan found in the novel Jemini, anak polah (children do not behave) means that every child has a wish, the father (parents) will grant their wishes, bapa kepradhah means the father will take the responsibility. This proverb is often used to satirize (comment on) parents who are too much for their children's will.

\section{The Sentence Style}

The sentence style section to be analysed is the problem of using long sentences and short sentences. In a work we often encounter sentences that are not in accordance with the prevailing linguistic rules. The deviation of the language rules is presented by the author to display aesthetic impression. The explanation of the deviation of sentence structure in the novel Jemini by Suparto Brata will later be explained.

\section{The Use of Long Sentences}

In communication activities, it is also seen from the style of interest, the sentence is more important and meaningful than just a word even though the style of the sentence is in many ways also influenced by the choice of words. An idea, a message can be expressed in various forms of sentences with different structure of vocabulary. In sentences, the words are related and are sequentially linear, which are then known as syntagmatic. The relationship can be seen in the form of graphological realization of the sentence in the form of lines like in a book. To be a sentence, the syntagmatic relationship of these words must be grammatical, in accordance with the system of rules that apply in the language concerned. Theoretically the number of words that are syntagmatic-ally related in a sentence is unlimited, it can be anything so it might be very long. Formally, indeed, there is no limit to the number of words that should be in a sentence, Chapman (in Nurgiantoro, 2007).

Sok ditutup nganggo topi pacul gowang, yakuwi topi sing sisih ndhuwur bathuk ana pecine, nanging pernah sirah sisih mburine krowak yen dienggo ketok rambute sing nganggo, topi sing khusus kanggo temanten lanang. $(J / 59)$

Sometimes it is covered with a broken hat, there is cap above forehead, but once back of the hat has a hole to cause the hair spurt, a specially designed hat for the groom.

In the novel Jemini by Suparto Brata, quote on page 59 which tells how Jemini was when she married Urip contained 32 long sentences. Appear in the sentence semile style. Although the sentence is quite long but by displaying such a beautiful atmosphere, the reader will not feel bored following the flow of the sentence. The figurative languages or in Javanese are called sanepa, shown in the quote above. Descriptions of the bride who are very beautiful and dashing in beautiful clothes are seen in the paragraph.

\section{The Use of Short Sentences}

Short sentences in stylistic terms are a number of words related to grammatical syntagmatic (Supriyanto, 2014: 65). The choice of using short sentences in inter-character utterances appears in the following quotation.

Sum! Ayo, ta, disaponi!" pambengoke Jemini. Yen sing pakon Jemini, swarane sentak, Sum lagi gelem ngeadeg. $(J / 128)$

"Sum! Come on, sweep the floor! " Jemini shouted. if the one who told Jemini, the tone gets higher, Sum would just stand up.

Part of dialogue above is taken from a conversation between Sum and Jemini. In the utterances "Sum! Ayo, ta, disaponi!" related to the sentence afterwards pambengoke Jemini. Yen sing pakon, Jemini, swarane sentak, Sum lagi gelem ngadek describing about Jemini's anger towards 
Sum. Sum was ordered by Jemini to sweep, but Sum ignored her. Jemini then repeats her command by snapping at Sum, in the end Sum wants to do Jemini's order. The use of short sentences shows anger, orders to be carried out immediately and sentences that are not negotiable.

\section{The figurative language}

The figurative language is indicated as a means used by the author to present a form of female struggle arranged epically through (a) decorative language: smile, personification, metaphor, figurative style, eponym language style, enumeration, sarcasm, (b) rhetorical means (c) repetition.

\section{The struggle for life of Javanese female characters in the novel Jemini by Suparto Brata}

The topic of the struggle of women carried in Jemini's is not far from the novels of its predecessors namely individual efforts (women) to find their purpose in life, freeing themselves from the shackles of social rules. The struggle of Javanese women in Jemini's shows a form of reality that is close to reality so that it is easily digested by the community. The characterization of women by carrying their domestic attributes as a strength and excellence in life becomes an interesting side in the novel.

The struggle for Javanese women begins with the personal awareness of women as part of a society that promotes the values of tradition as a noble heritage of culture that raised the nation. The struggle of Javanese women featured in Jemini's shows the behaviour of Javanese women who do not prioritize their individual sides. We can see this in five things which are the main points of the struggle of Javanese women in Jemini's; First, Javanese women appear as figures who serve their families. Jemini is the first daughter born in her family, indirectly Jemini is demanded to be an example for her younger siblings. Jemini, who is still young, is not accustomed to being lazy or spoiled. Jemini has an obligation to help her parents do household chores.
Secondly, Javanese women as members of the community must obey the customary rules that apply to maintain peace in social life. When Jemini entered adolescence and experienced a menstrual phase, Jemini was confronted with a local customary problem which assumed as a women ngarap sari (reach her period) is women who is already adults so they were ready to get married. In Javanese customs, the matter of feeling is not important. In general, parents will give advice to their daughters that as a woman can only accept and that emotional feeling can be fostered over time, they will get used to love each other. An unmarried Javanese woman is considered to be a shame to herself or her family. Conversely, Javanese women are considered as successful individuals if they marry at a young age. Thus, this is also the background of forced marriage and early marriage.

As individuals born in Javanese society we sometimes have to hold back (not rebel) or not show our hearts to maintain harmony in social life, especially to parents who have brought us into the world. Although Jemini resigned to the matchmaking she experienced, Jemini's submissiveness is a form of love and devotion to parents. Parents, as representatives of their lives and settings, are entitled to the highest honor and children must serve, that is, respect and devotion to parents as a half religious procedure. As parents, their obligation is not only to produce offspring but also to educate them to become humans, to be Javanese, while equipping them with the provisions needed to travel through life to find a mate (Mulder, 1996).

Therefore, Jemini's character then goes on to have an arranged marriage as a form of devotion to her parents. Accepting arranged marriages is a form of struggle for a woman in fighting her ego that humans are born not only live for themselves personally but also consider others, especially parents who present us in the world. Basically, the superiority of Javanese women is to have an attitude of acceptance (obedience) even though compliance can cause friction in their hearts.

Thirdly, Javanese women are skilled in managing household domestic needs. In an 
illustration of the story of Jemini's depicted a female character woke up early and went to sleep last to complete household chores related to the kitchen, cleaning, caring for children to take care of her husband's needs, it was coupled with other jobs such as trading to help with the needs his family's economy. Javanese women will feel satisfied when they can accomplish their household tasks on time.

Fourth, women maintain harmony in their household. Women in powerlessness are still able to think rationally so that they do not necessarily run away or report actions taken by Radian to their parents. Jemini tried to hold back her sufferings so as not to cause concern or even new problems in her family. Telling their partner's disgrace is the same as telling their own disgrace because the wife is the clothes of the husband and the husband is the clothes of the wife so that whatever happens a wife or husband is not encouraged to indulge in mutual ugliness. In terms of speaking the language of the female characters in Jemini's 1 also shows tenderness and politeness and does not degrade other people especially men. This shows that Javanese women can act more tactically and rationally in maintaining the harmony of their family even in stressful situations.

Fifth, Javanese women, as mothers, provide protection for their love and their children's growth and development. Being a mother is the greatest achievement in women's lives. The existence of a woman at the beginning of a child's life is a spirit that blows affection in the lives of her children. Taking care of the children born to adulthood and getting a decent life is the most beautiful thing in a woman's life. The presence of a mother in the middle of the family carries the burden of idealization which is also the reason why she must be respected

Sixth, Javanese women are able to nrima (accept) a condition in their lives. Jemini's calmness showed that Javanese women were not in a hurry to face a difficult condition. The calm nature that Jemini shows with the word/ora susah-susah/ is a condition called nrima. The attitude of acceptance is part of mastery over emotional with the belief that there is still hope for a better tomorrow because God should have determined the fate of each of his creatures. Jrimini's nrima does not mean that she does not try, Jemini continues to fight for her better fortune, but if hope is not achieved Jemini hopes that what she does will have a good impact on others, especially for those she loves.

Seventh, Javanese women are independent or not dependent on men. Jemini After Piet's departure, Jemini continued her life with Linda Jemini did not think of remarriage even though Piet returned to his country. This shows that Javanese women are independent figures so that they do not only depend on men in their lives

Eighth, Javanese women maintain loyalty. The loyalty of Javanese women was seen when the Jemini figure was left by Piet to Netherland. Piet promised to return immediately within six months, but apparently Piet could not return within the promised time. Jemini did not necessarily turn away from Piet, Jemini still waited for Piet until Piet came to see him.

Ninth, Javanese women who fight for the fate of their people (women). In addition to Jemini fighting for her fate, Jemini also cared about the fate of other female figures, including Siti and Kadinah. This can be seen when Jemini is concerned to see the situation of Siti left by Oom Slompret who returned to the Netherlands with her three children. Siti is powerless to bring her children because her position is only as a key so that she does not have the rights to her children, so at that time Jemini tried to comfort Siti. Whereas Jemini's concern for Kadinah was seen when Kadinah was feeling uneasy because of her jealousy towards Siti women in her husband Den Sutras' past, Jemini tried to calm and convince Kadinah that this was just her feelings. Jemini also helped Kadinah while Kadinah was in pain during childbirth. Jemini is a wise woman in attitude so that in the positionof Kadinah's inner struggle, Jemini is someone who is able to reconcile Kadinah and Siti. 


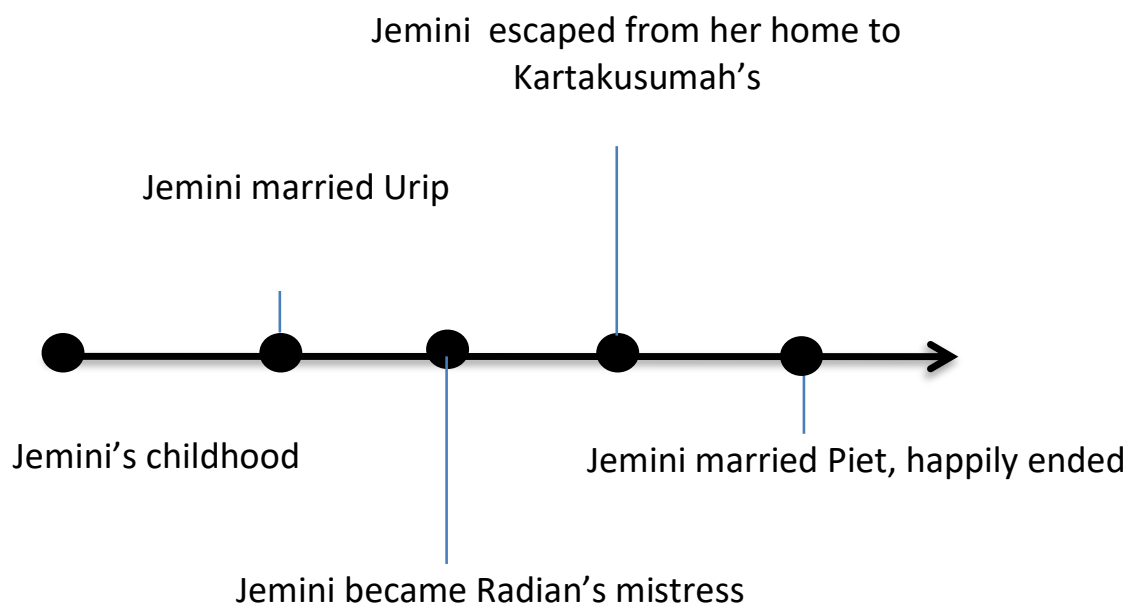

Figure 1. Plot of the struggling of female figures

The plot arranged in the opening or matching section tell about Jemini in childhood. The flow restrictions in this section are found on pages 1 to 40 of the story. The theme in this part of the plot is Jemini's misbehavior that goes beyond boys. The second strand is an introduction that contains the events of Jemini as a teenager. This story is found on pages $41 \mathrm{~s} .72$. The theme carried in this section is the life story of Jemini when she married early and divorced her first husband (Urip), because of the traumatic nature of having sex. The third part is the conflict summarized on page $73 \mathrm{~s}$. 103. This section tells the story of Jemini who was tortured while being locked up by Den Radian. The theme that carries this part is the issue of self-education which is important to save the future. This was evident when Jemini felt confused about running away from Radian, because she was inexperienced and unable to read and write. The fourth channel is the peak that contains the escape of Jemini from Radian's house. The story is found on pages 103 to s. 117, which tells the story of Jemini's journey from Betawi to Kartakusumah, rescues herself at Wak Talib's house. The theme of this section is the courage to make decisions. After the escape, Jemini must have been considered wrong by Radian and the community. However, this decision is better, if compared to settled and died tortured by Radian. The fifth channel is Jemini's life with Piet Coertszoon (Landa Dawa), which is told from pages 117 to 191 . The sweet love story of someone of different races and religions is an interesting segment in this novel. The theme of this part of the plot is trust between partners. Finally, their lives were blessed with a beautiful daughter, Linda. Happily ended.

\section{CONCLUSION}

The results of study of the novel Jemini by Suparto Brata presented in this chapter include (1) the characterization of Javanese women in the Jemini's (2) the style of words, sentences and figurative language in the novel (3) the life struggles of Javanese female characters in the novel. Javanese female figure in the novel; ten figures consisting of one main female character namely Jemini and nine additional female figures namely Emak Semi, Ngadinem, Mak Raji, Siti, Kadinah, Makne Siti, Sum, Mak Talib, Parni. The language style of the female characters in Jemini's consists of; words, sentences, phrases, figurative languages indicate the existence of feminism in the text of the novel Jemini by Suparto Brata. Word style seen from (1) word choice; (a) the use of foreign languages, (b) the use of local languages (2) the use of synonyms: (a) the use of compound words, (b) the shortening of words, (c) the use of re-forms, (d) deviation of basic forms. (3) phraseology, using phrases derived from Javanese, (4) sentence style: (a) the 
use of long sentences, (b) the use of short sentences, (5) Figurative language (a) the language of class: smile, personification, metaphor, figurative style, eponym language style, enumeration, sarcasm, (b) rhetorical means (c) repetition.

The character of Javanese women in Jemini's is clever, broad-minded, always curious, shameless, agile, nimble, diligent in working, strong-minded, patient and accepting, sympathetic, respectful towards parents, adults. The struggle for life of Javanese female characters in the novel Jemini by Suparto Brata is; first Javanese women appear as devoted figures to their families, second Javanese women as members of the community must comply with customary rules that apply to maintain peace in social life, third Javanese women are skilled in managing the domestic needs of their households, Fourth, Javanese women maintain harmony in their households, Fifth women Java as a mother provides protection for her love and growth and development, six Javanese women are able to accept a condition in their lives, seven Javanese women are independent or not dependent on men, eight Javanese women maintain loyalty, nine Javanese women who fight for the fate of their people (female).

\section{SUGESSTION}

The identification of novels containing feminism is able to ignite the spirit of novel writers composing works that contain the struggle for gender equality between men and women, without leaving local cultural elements (Javanese). The character of feminism contained in the novel hopefully can be applied and understood wisely, if it is indicated to have a strategic function for life in society. The feminism movement is a movement to change the character of women and men to be able to create a better life, so that everything that is inserted in this education must be purely on the basis of the common good.

\section{REFERENCES}

Asri, Yasnun. (2013). "Refleksi Ideologi Wanita Minangkabau dalam Novel Negeri Perempuan Karya Wisran Hadi "dalam Humaniora. No. 1 hlm. 69-81..

Faizin, dan Agus Nuryatin. (2017). "Religiusitas dalam Syair-Syair Tegalan Karya Imam Chumedi". Seloka: Jurnal Pendidikan Bahasa dan Sastra Indonesia. 6 (1).

Handayani, Cristina. S, Ardhian Novianto. (2008). Kuasa Wanita Jawa. Yogyakarta. LKiS Yogyakarta.

Junus, U. (1986). Sosiologi Sastra: Persoalan Teori dan Metode. Kuala Lumpur: Dewan Bahasa dan Pustaka.

Luthfiani, Rustono, dan Wagiran. (2020). "Meaning Patterns and Potential Forms of Halle Deadjektival Verbs Model in Generative Indonesian Morphology". Seloka: Jurnal Pendidikan Bahasa dan Sastra Indonesia 9 (1).

Mulder, Nilels. (1996). Pribadi dan Masyarakat di Jawa. Jakarta: Sinar Harapan Aanggota IKAPI.

Pradopo, Djoko Rachmat. (2009). Beberapa Teori Sastra Metode Kritik, dan Penerapannya. Yogyakarta: Pustaka Pelajar.

Susanto, Budi et all. (1992). Citra Wanita dan Kekuasaan (Jawa). Yogyakarta: Kanisius.

Supriyanto, Teguh. (2014). Kajian Stilistika dalam Prosa. Yogyakarta. Elmatera Publishing.

Supriyanto, Teguh. (2011). "Relasi dan Negosiasi Ideologis dalam Naga Sasra dan Sabuk Inten Karya SH Mintarja." Artikel. Jurnal Humaniora. Vol. 23 (-1), hlm. 1-16.

Udayana Hildan dan Bambang Indiatmoko. (2017). "Ekspresi Cinta dan Citra Religiusitas dalam Novel Atheis karya Achdiat Kartamiharja. Seloka: Jurnal Pendidikan Bahasa dan Sastra 6 (2).

Valentina. R. (2010). Pengalaman-Pengalaman Aku yang Perempuan, Laki-laki Feminis. Jakarta Selatan: Pengasuh Rubrik Budaya.

Wolf, Naomi. (1994). Fire with Fire: The New Female Power and How To Use It. New York: Vintage Books. 
Krisnani Widyaningsih, et al./Seloka: Jurnal Pendidikan Bahasa dan Sastra Indonesia 9 (2) (2020) : 147 - 158

Yasa, I Nyoman. (2014). Poskolonial Teori dan Penerapannya dalam Sastra Indonesia Mutakhir. Yogyakarta: Graha Ilmu.

Zulaeha, Ida. (2013). "Innovation Models of Indonesian Learning in Multicultural
Society." Article. Proceding: Soscial and Behavioral Sciences, International Educational Tecnology Reference, 103 (2013) $506-514$. 